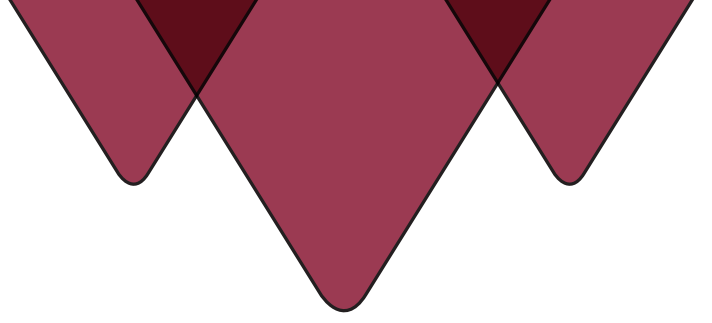

\title{
Library Councils and Governance in Canadian University Libraries: A Critical Review
}

\author{
Eva Revitt \\ MacEwan University \\ Sean Luyk \\ University of Alberta
}

\begin{abstract}
Despite the nearly 40-year history of library councils in Canadian academic libraries, scholarly literature regarding library governance and decision-making processes within the context of Canadian university libraries is almost nonexistent. Nevertheless, there is evidence of a general disenfranchisement of librarians from significant decisions affecting library operations, resources, services, and the appointment and evaluation of senior administrative positions. Furthermore, it is evident that library councils in Canadian academic libraries, where they do exist, function primarily as information-sharing forums rather than as the collegial decision-making bodies they were originally intended to be. Through a close examination of the CAUT Bulletin, this paper traces the development of library councils in Canadian academic libraries. Within the framework of institutional theory and drawing from librarianship, management, and educational administration literature, the paper proceeds to critically discuss systematic barriers to collegial governance in academic libraries. Historical and anecdotal evidence suggests that administrative resistance is a continued and key obstacle to the democratization of decision-making processes in Canadian academic libraries.
\end{abstract}

Keywords: academic librarians - academic libraries - institutional theory . library councils - library governance

RÉSUMÉ

Malgréle fait que les conseils de bibliothèques existent maintenant depuis près de 40 ans dans les bibliothèques universitaires canadiennes, les publications savantes concernant la gouvernance de la bibliothèque et le processus de prise de décision dans le contexte des bibliothèques universitaires canadiennes sont presque inexistantes. Néanmoins, il existe des preuves d'une exclusion générale des bibliothécaires du processus de prise de décision concernant les opérations de la bibliothèque, les ressources, les services, ainsi que la nomination et l'évaluation de ceux qui occupent les 
postes administratifs. En outre, il est évident que les conseils de bibliothèques des bibliothèques universitaires canadiennes, là où ils existent, servent essentiellement de forums de partage d'information plutôt que d'organes de prise de décision collégiale, ce qu'ils étaient initialement destinés à être. Grâce à un examen attentif du Bulletin de l'ACPPU, l'article retrace l'évolution des conseils de bibliothèques dans les bibliothèques universitaires canadiennes. Utilisant le cadre de la théorie institutionnelle et puisant dans la documentation des domaines de la bibliothéconomie, de la gestion, et de l'administration de l'éducation, l'article procède à l'examen critique des obstacles systématiques à la gouvernance collégiale dans les bibliothèques universitaires. Les preuves historiques et les témoignages suggèrent que la résistance administrative est un obstacle majeur et continu à la démocratisation du processus de prise de décision dans les bibliothèques universitaires canadiennes.

Mots-clés : bibliothécaires universitaires · bibliothèques universitaires conseils de bibliothèques · gouvernance de la bibliothèque · théorie institutionnelle

D ESPITE the 40-year history of library councils in Canadian university libraries, and the widespread endorsement of collegial governance for academic librarians by the Canadian Association of University Teachers (CAUT) and the Association of College \& Research Libraries (ACRL), ${ }^{2}$ the scholarly literature regarding library governance structures and decision-making processes within the context of Canadian university libraries is almost nonexistent. What is found is primarily grey literature, such as unpublished reports, conference proceedings, and associations' statements and newsletters. Nevertheless, there is evidence of a general disenfranchisement of librarians from significant decisions affecting library operations, resources, services, and the appointment and evaluation of senior library administrative positions (Jacobs, 2008; Granfield, Kandiuk, \& Sonne de Torrens, 20II; Petter, 2012; Ribaric, 20I4). Library councils, where they exist and in the degree to which they are effective, function primarily as information-sharing forums rather than the decision-making bodies they were originally intended to be. Furthermore, there appears to be a lack of common understanding, if not confusion, about the functions, goals, and purpose of the library councils (Jacobs, 2008, p. 15). Within the framework of institutional theo$\mathrm{ry}^{3}$ and drawing from the literature on librarianship and educational administration, this paper reviews the development of library councils and critically examines current approaches to collegial governance in Canadian university libraries.

At its most basic, governance is "the structure and processes by which decisions are made" (Sporn, 2006, p. I43). However, the concept is complex, contextual, distinct from management and leadership, and includes dimensions of authority, power differences, negotiations, decision-making styles, and accountability. How one defines governance depends on one's field of study. For the purposes of this paper, it is 
assumed that governance, through legislation, institutional statutes, policies, bylaws, and informal norms, determines who has the power, who makes the decisions, and how stakeholders make their voices heard (Bradshaw \& Fredette, 2009; Institute on Governance, 2015; Sporn, 2006).

In academia, successful shared or collegial governance depends on active academic staff participation, mutual trust and respect, and shared responsibility for institutional welfare. ${ }^{4}$ For librarians, collegial governance can be measured by how much input librarians have into the priorities, planning, and policies of the library as well as participation in institutional committees and policy work that transcend the library. ${ }^{5}$ Library councils, or librarians' councils as they are sometimes called, are governance bodies paralleling faculty or school councils. Faculty or school councils typically consist of all full-time academic staff members and have powers and duties defined by provincial or university statutes. In sharp contrast and with few notable exceptions, ${ }^{6}$ library councils today appear to exist at the discretion and benevolence of the university librarian or title-equivalent. An examination of the historical context and evolution of library councils reveals that the establishment of collegial governance structures, once considered an inevitable outgrowth of librarians' achieved academic status, is marked by "fits and starts," sexism, and administrative hesitance.

\section{Literature Review}

A key source of information about the development and the function of library councils in Canada is the CAUT Bulletin (hereafter Bulletin). By examining the Bulletin from its first issue in 1953 to the present day for librarian-related articles, a revealing thread emerges that chronicles the development of academic status for Canadian academic librarians and how the library council is promoted as the ideal collegial governance body.

As academic status for faculty and its concomitant benefits were developed and debated in the 1960s, ${ }^{7}$ the topic of collegial governance structures for librarians in Canada began to enter the discourse as well, but it did not make its way into publications until the mid-I97Os. In the May 1975 Bulletin, a news brief concerning Carleton University librarians' membership in the newly formed faculty union (CUASA) stated that the "main concerns and reasons for affiliation to the faculty union ... include the recognition of librarians' status as academic staff and improvement of their position vis-à-vis participation in university and library governance" ("Librarians Join," 1975, p. 6). A follow-up article regarding the ratification of the first collective agreement at Carleton noted that the contract established a University Library Committee, which was concerned with library governance. There was also a 
Peer Evaluation Committee that made recommendations to the university librarian and the president regarding promotions and permanent appointments (Masleck, I975, pp. I-3). Although the article did not mention a library council by name, the University Library Committee at Carleton was likely an early example of what we would now refer to as a library council, given its role in library governance and participation in internal peer review.

The development of the Guidelines on Academic Status for University Librarians (hereafter Guidelines) brought collegial governance to the forefront (Canadian Association of University Teachers and Canadian Association of College and University Librarians, 1976, pp. 19-22). The March 1976 issue of the Bulletin was focused on librarian issues and contained a special report on academic librarianship, which covered such topics as librarian membership in CAUT (Evans, I976), collective bargaining (Moore, 1976), salaries (Bell \& Watson, 1976), governance (Beckman, 1976), and threats to intellectual freedom (McGregor, 1976). Most importantly, in this issue were the Guidelines themselves, which placed the library council at the centre of collegial governance for academic librarians, stating that

\footnotetext{
All librarians should be members of a Library Council which is chaired by the Chief

Librarian. The Council should have responsibility for the development of policies and procedures for the operation of the library as a whole and should be responsible to the Senate or equivalent body. (CAUT \& CACUL, I976, pp. 22)
}

It is significant that the Guidelines strongly established the link between the library and the senate or equivalent governing body. By connecting the library to the university's senior academic body, as teaching faculties typically are, the library, and by extension the librarians, were firmly rooted in the academic arm of the university, thereby recognizing the necessity of collegial governance for librarians. In turn, the associated connection emphasized the status of librarians as members of the academic community. One proponent of the Guidelines celebrated this point by stating, "the Guidelines recommend that librarians accept their role as an integral part of the educational process ... a change to a collegial structure and ranking of librarians positions will speed the process along" (MacPherson, I977, p. IO, emphasis added).

To this day, the idea that an academic library should be governed analogously to a teaching faculty remains controversial, and one's perspective on the issue may in part reveal the distinction that Leona Jacobs makes in her 2008 survey of Canadian library councils between "those of us wishing to be academic LIBRARIANS and those of us wishing to be ACADEMIC librarians and those of us wishing to be, simply, academic librarians" (Jacobs, 2008, p. I5, emphasis in the original). It is perhaps not a surprise, 
then, that when the Guidelines were released, they had their share of critics from the "librarian first, academic second" camp.

Margaret Beckman, chief librarian at the University of Guelph, wrote an article on library governance that made arguments still echoed today (Beckman, 1976). Beckman believed that while academic librarians and teaching faculty shared similarities, these were outweighed by the differences, and this she argued was mostly due to the "production line" nature of the library and the need for final decision-making power by chief librarians in times of urgency (p. 22). If the development of library policies had to go through a library council, the library system would be

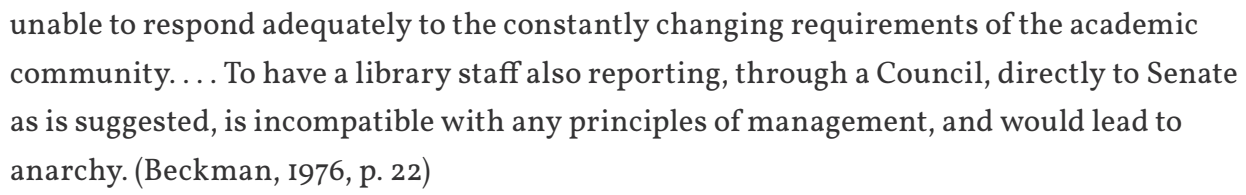

Beckman called instead for an alternative governance model somewhere between the hierarchical and the collegial, which she referred to as participatory. The participatory model was also recommended by the Association of Research Libraries (Booz, Allen, \& Hamilton, 1973).

In the participatory model, librarian involvement in decision-making is achieved through participation in committees that ultimately report to the chief librarian via some sort of senior management committee. Although the participatory management model, which many Canadian academic librarians may find themselves working under today, has many attractive features, it misses the mark in providing academic librarians with one of the cornerstones of academic status: collegial governance, where decision-making is not mediated by bureaucracy and where rank-and-file librarians and library administration participate in decision-making as peers and share responsibility for the organizational welfare of the academic library.

Tom Eadie, Arts Reference and Collections Head, University of Waterloo, observed that the 1960 s Canadian post-secondary education boom created an oversupply of librarians, forcing libraries to hire more competitively (1978). According to Eadie, this resulted in librarians having more affiliation with faculty than the previous generation, due to their higher academic qualifications. This, he argued, "resulted in a new population of librarians more interested in affiliation with faculty because of their academic background ... than the older generation" (p. I4). However, rather than using the changing demographics of academic librarians as an argument in favour of collegial governance for academic librarians, Eadie argued that collegial governance would not work in a library context due to the number of support staff employed in libraries (which he claimed was at a ratio of 4:I to librarians). Because of this, according to Eadie, the majority of librarians were required to be managers 
and therefore did not have the time to be part of a collegial governance process. Eadie also claimed that "there is a requirement that a library department function as a team, in a way that an academic department is rarely required to do-this makes the library department head more of a manager than his academic counterpart" (p. I4). Although the requirement for most librarians to be managers may have been the case in 1978 , many of us can attest that this is no longer true, ${ }^{8}$ nor is it accurate that faculty members are not required to work in a team environment. Eadie's points were just some in a string of arguments against collegial governance for librarians that hinged on the idea that "librarians are different."

Aside from the detractors of collegial governance for academic librarians following the adoption of the Guidelines, there were also some supporters and evidence of functioning library councils. By I977, both York University and Laurentian University had library councils, as indicated in the Bulletin. York's library council was more administrative in nature than a faculty council, but its existence "recognize[d] collegiality, and therefore, participative management" (Monty, 1977, p. Io). The functions of the York University Library Council at that time were to deliberate on library policy, provide advice to the director of libraries (equivalent to the university librarian today), receive and respond to the library plans and progress reports from the director, and legislate committee policies and procedures (Monty, I977, p. IO). There are fewer details about Laurentian's library council at this time. Laurentian's council made recommendations on the affairs of the library, and the chief librarian was an ex officio member of the council who generally accepted its recommendations (Thompson, 1977, p. II). While York's library council has since been disbanded, the authors have recently learned that York is working toward its revival. Laurentian's library council exists to this day, and its functions are confirmed in the collective agreement, as is the principle of collegial governance. ${ }^{9}$

By the late I970s, many librarians had made gains in securing participation in university governance; developing collegial governance structures within the academic library was, however, an arduous process, complicated by other workplace challenges, including the attainment of faculty status, sabbatical leaves, and pay commensurate with faculty. At a I979 western regional meeting of CAUT in Edmonton, it was noted that

Though academic librarians are members of University Senates and General Faculties Council in some universities there appears to have been less progress in ensuring an adequate voice for librarians in developing policies and programmes within university libraries. Chief Librarians still maintain great autonomy and Library Councils analogous to Faculty Councils have been slow to develop. (Sim, 1979, pp. 6-7) 
An argument can be made that not much has changed in library governance since then.

In a 1980 issue of the Bulletin, Ellis presented a more complete discussion of library councils that examined their potential fit and function within wider university governance structures. Ellis made three key recommendations. First, a library council, constituted of all academic librarians on staff, should consider all matters of policy (academic and non-academic) and should be responsible for the "initial formulation of academic policy originating in the library policies which would subsequently be considered by senate" (p. Io). Second, the senate's library committee would need to be modified to work more like other senate committees, and it would be charged with ensuring that proposed academic policies were in line with existing ones. And third, increased presence (by election) of rank-and-file librarians to senate would move toward further embedding the library into wider university-governance structures. Ellis admitted that one of the major challenges would be to determine which policies affect academic matters. The authors argue that the distinction between "academic matters" and all other matters is a false dichotomy that serves to strengthen administrative managerial reach at the expense of professional expertise and autonomy. We will return to this point later in the paper.

In 1988, CAUT conducted a survey of library councils to determine their prevalence and effectiveness, the results of which were published in the Bulletin (Moore, 1988). The results were not promising, or surprising. For the ten responding institutions, the author noted that it appeared that library councils offered a "weak form of collegiality or of governance by rank-and-file librarians" (Moore, I988, p. 9). The survey prompted more debate on the topic, including Vine's article on the internal dispute-resolution process shepherded by the Library's Committee on Professional Conditions at the University of Calgary and St. Jacques's article on the importance of a clearly articulated library council mandate in the collective agreement (Vine, I988; St. Jacques, I988). Governance continued to be a topic discussed by the CAUT Librarians' Committee in the Bulletin throughout the late I980s and early I990s, often alongside bigger-picture discussions of academic status.

CAUT's 1993 report of the Independent Study Group on University Governance (ISGUG Report) prompted renewed interest in library governance and was significant for its insistence that library councils function similarly to faculty councils and that the chief librarian occupy a role much like that of a dean. The ISGUG Report also provided some clarity on a few controversial points. It recommended that the library council be the venue where budget proposals were initially discussed and debated. It also reaffirmed the notion that the library council is more than a mere advisory body, 
and that there should be no confusion between the two. The report also raised the troubling issue of sexism, emphasizing the gendered nature of the profession:

[Libraries are one of the] few areas in the university with a large number of women with professional qualifications. It is not, therefore, surprising that some of them see this attitude as a form of discrimination against women. University libraries should be operated in a fair and constitutional manner, just as faculties ought to be. (CAUT, 1993, p. 49)

The patriarchal nature of academic library management today ${ }^{\mathrm{IO}}$ should be a cause for concern for all of us and something that could perhaps in part be remedied by a wider acceptance of collegial governance models in academic libraries.

The ISGUG Report, and a necdotal evidence of library councils functioning poorly, sparked a series of five vignettes discussing library council circumstances in various Canadian academic libraries in the June 1997 Bulletin issue (Sheeran et al., 1997). The case studies revealed varying levels of participation in wider university governance, none of which seemed satisfactory and none of which reported strong library councils with decision-making powers. Ruth Sheeran, chair of the CAUT Librarians' Committee, advocated for stronger library councils throughout her tenure on the committee, drafting both an information paper on governance and librarians and a model clause on library councils (Peters, 1999). Sheeran reminds us that if "the library council does not function productively as a collegial governance body within the library, then the librarians should work to change it" (Sheeran, 1998).

In recent years, CAUT has been a vocal proponent of library councils, with the CAUT Librarians' Committee producing a discussion paper in 2007 that reviewed the history of library councils in Canadian academic libraries and echoed the characteristics of the ideal library council first introduced in the Guidelines. The discussion paper also differentiated between a library council and a management body, warning that "a failure to distinguish between the two functions can result in problems if the administrators fear that the library council will encroach on their managerial responsibilities" (CAUT Librarians' Committee, 2007, p. 4). Perhaps the reluctance of senior library administration to accept a collegial governance model in their libraries is a conflation of management with governance.

More recently, Jacobs's 2008 survey of Canadian library councils is helpful in identifying which libraries have councils, their composition, and lessons to be learned. Jacobs notes that "there is not widespread implementation of library councils" (p. I3), although similar bodies may exist under different names. Jacobs received responses from 25 academic libraries, 13 of which had library councils or like bodies. Her survey revealed a few interesting observations. First, and not surprisingly, institutions with a more flat, as opposed to hierarchical, management structure were more likely to have library councils. Second, the majority of library 
councils are chaired by the university or chief librarian, which is recommended by CAUT, but some respondents felt that this was problematic. Third, only five of the responding institutions' library councils reported directly to their senate or equivalent. Jacobs also asks some key questions at the close of her study:

Is the idea behind the concept of a library council about the emulation of faculty structures so that they will accept us as academic staff? OR is it about a structure that truly has merit for determining and accomplishing the goals of the library? Can it be both? (p. 15, emphasis in the original)

If the library council as the ideal governance body for academic librarians has been touted by CAUT and others since the I970s, and various reports, statements, and endorsements from library associations have affirmed it as the appropriate way for an academic library to be governed, why do so few of our libraries in 2015 have functioning library councils? To understand this paradox, we examine the current state of library councils within the framework of institutional theory and proceed to critically discuss systemic barriers to collegial governance in academic libraries.

\section{Institutional Theory}

Institutional theory examines why organizations tend to look and act the same (Miles, 20I2). An institution, within the context of institutional theory, is not easily defined. It is not a single entity but rather the effects that the environment-the established social structures, norms, expectations, and routines-have on an organization (Austin \& Jones, 2016; Scott, 2005). Institutional contexts can strongly influence the development or adoption by organizations of structural forms such as job titles, procedures, established hierarchies, or management models. Arguably, academic libraries are a similar organizational type situated within a similar institutional context-an establishment of higher learning that is part of the post-secondary educational sector. It is for this reason that librarians as academic staff ${ }^{\text {II }}$ have expectations of professional autonomy and collegial governance via a constituted council paralleling that of their academic staff counterparts. Academic libraries share more than just their academic context, however. Academic libraries interact with the same key suppliers and vendors, they offer similar services, are subject to a similar legal framework, and employ professional and para-professional staff drawn primarily from the same discipline.

In their classic article, "The Iron Cage Revisited," DiMaggio and Powell (1983) assert that the homogeneity among organizations is the result of isomorphism, or pressures that "force one unit in a population to resemble other units that face the same set of environmental conditions" (p. I49). Over time, organizational practices, structures, and processes become stabilizing components, and a threshold is reached 
when their adoption by other organizations provides legitimacy without necessarily improving effectiveness. Conformity rather than performance propels organizational change. As structural forms are legitimized, failure to conform is regarded as nonsensical, negligent, or irresponsible. Organizations become more similar without becoming more effective. Institutional theory can help us understand why, despite mounting evidence supporting the effectiveness of group decisions and deliberative bodies within the academic context (Griffith, I993; Eckel, 2000; Bradshaw \& Fredette, 2009; Koufogiannakis, 2015), key decisions affecting library resources, services, and librarians' work remain the purview of a few senior library administrators rather than deliberative bodies such as library councils (Jacobs, 2008; Ribaric, 2015).

DiMaggio and Powell (1983) identify three isomorphic pressures that contribute to organizational homogeneity: coercive isomorphism, which results from the use of power or legal mandates by entities that the organization is dependent on, such as government, laws, or other organizations; mimetic isomorphism, when organizations, particularly during times of uncertainty, model themselves after other organizations that are perceived to be more successful; and normative isomorphism, which stems from professionalization and the affirmation that results from formal education, professional networks, standards, and established practices of professional groups. Arguably, within the context of the academic library, all three isomorphic pressures are at play. Coercive isomorphism is felt when key industry players such as e-book publishers or database vendors monopolize a service or when professional associations such as ARL adopt a particular assessment framework. ${ }^{12}$ Mimetic isomorphism is evident in the recent emphasis to reinvent the value of academic libraries in the internet age (Oakleaf, 20IO), while normative isomorphism is perhaps best exhibited in the career-track focus of senior library administrators.

The professionalization of administration is particularly troubling. There is evidence that within academia, consultation and the facilitation of democratic decision-making processes are considered an important facet of effective leadership at both the departmental and institutional level (Bryman, 2007b). The practice of "stepping back into faculty ranks" after a period of administrative service is almost unheard of in academic libraries (Ridley, 20I4). Senior administrative appointments are achieved career milestones with no pretense of continuing professional practice. As such, it is easy to imagine how senior administrative positions are more aligned with practices of corporate management than enshrined academic values of collegial governance. DiMaggio and Powell (1983) explain that the "filtering of personnel" which occurs through the hiring from like organizations, desiring like skills, and using like promotional practices via closely guarded career tracks, renders many top professional administrators virtually indistinguishable, as, "filtered by a common 
set of attributes, they will tend to view problems in a similar fashion, see the same policies, procedures and structures as normatively sanctioned and legitimated, and approach decisions in much the same way" (p. 153). Historical and anecdotal evidence suggests that administrative resistance is a continued and key obstacle to the democratization of decision-making processes in Canadian academic libraries.

\section{Collegial Governance: Is It Effective, and Does It Matter?}

Collegial governance processes are mocked as petty and criticized as causing unnecessary delays through extended debate (Crellin, 20Io). Administrators argue for the need for flexibility, accountability, and timely responses to rapidly shifting external demands and environments (Meyer, 2007). Rank-and-file faculty are accused of territoriality; lack of business acumen; or being too busy, uninterested, or preoccupied with self-serving research agendas, career advancement, and prestige (Steele, 20I0). While no doubt these sentiments may ring true for some individuals and contexts, the notion that deliberative bodies such as library councils cannot make tough decisions, as previously asserted by Margaret Beckman (1976), is simply unfounded. Within an I8-month period, the University of Maryland lost \$45 million, or 20 percent, of its state-funded budget (Griffith, I993). University administration embarked on an extensive consultation process. The faculty were involved and participated in every key decision. The result was the elimination of 29 degree programs, seven departments, and one college. Faculty proved that they were capable of bleeding their own ranks and making tough decisions when the situation demanded. Eckel (2000) conducted case studies in four universities and found that faculty were willing and able to make the difficult decision to cut programs for the benefit of the university. In a study reviewing the effectiveness of Canadian university senates, Jones, Shanahan, and Goyan (200I) make the point that the efficiency of deliberative bodies in dealing with budgetary matters has not been tested, because many are simply not given the opportunity to deal with these issues. In a follow-up study seeking to determine change in the role and function of the senate in Canadian universities, Pennock, Jones, Leclerc, and Li (2012) found that only one of the 38 surveyed institutions included a senate with approval power over budgetary matters, but the decision could be overturned by a two-thirds majority of board members.

In a qualitative study exploring effective decision-making and evidence use among Canadian academic librarians, Koufogiannakis (2015) found that the largest obstacle to both was organizational dynamics:

Problems can occur both within the hierarchical structure of the organization and among peers. A workplace that is not functioning well due to poor leadership, or a senior manager who is overly controlling, interfere with good decision making. (p. IO4) 
However, positive organizational dynamics served to facilitate effective decisionmaking and use of evidence:

If the culture of the organization is one that allows open discussion and values the use of evidence in decision making, academic librarians are enabled to practice in a way that they feel very positive about... Supportive groups that can work well together, with common goals, also enable the decision-making progress. (p. I05)

It seems reasonable to assume that open, collaborative, group discussion, as facilitated by a deliberative body such as a library council, would promote effective decision-making. However, existing library councils appear to be limited in their scope and function (Jacobs, 2008; Ribaric, 20I3).

Ribaric's (20I4) article, "Collegial Self-Governance for Professional Librarians: The Establishment and Evolution of a Library Council at Brock University," is the only recent scholarship exploring the functions of a library council within the Canadian context. The existence of the Brock University Library Council was enshrined in the Agreement on the Terms and Conditions of Employment for Faculty between the Brock University Faculty Association and Brock University (Brock University, 1997). The Library Council was "empowered to create its own rules of procedure to suit its own needs ... and render verdicts in the adjudication of library matters" (Ribaric, 2004, p. 283). Ribaric notes that Brock's Library Council was "intended to function as a policy-making body" (p. 28I); in reality, however, the primary preoccupation of the council appears to be peer review. "The bulk of business conducted by Library Council is not participation in library planning but that of collegial review" (p. 286). The contrast between the council as originally envisioned and operational reality is stark but aligns with Jacobs's (2008) original findings. Of the 25 libraries that responded to Jacobs's survey, only iz had a library council or similar body. Of these, not one library council was perceived by the respondents to be an effective decision-making body.

In sharp contrast, established collegial and democratic decision-making processes are evident in some of the world's most prestigious organizations ${ }^{13}$ and even enacted in law at the national level. ${ }^{14}$ Harvard University and Yale University, two of North America's most esteemed institutions of higher education, are both recognized for their strong faculty governance and well-established collegial decision-making processes. ${ }^{15}$ Interestingly, we continue to question the value of democratized and collegial decision-making but not the effectiveness or impact of centralized, topdown directives. In an extensive review of the literature focused on leadership effectiveness in higher education, Bryman (2007b) makes the point that managing professionals is not the same as managing other groups of employees. Professionals need independence and "require a different, or more subtle, form of leadership than non-professionals" (p. I7). They appreciate protection and support, but an integral 
and distinctive expectation of academic staff is respect for autonomy and democratic decision-making. There is evidence that strengthened governance processes and the fostering of collegiality, including both democratic decision-making and mutual cooperativeness, are important in attracting and retaining top academic talent (Meyer \& Evans, 2003), are more important than dissatisfaction with salary (Olsen, I993), and are positively correlated with institutional financial performance (Cunningham, 2009). The professional's limited need for direction of task and high need for autonomy may be the reason for academics' general resentment of managerial and administrative encroachment (Teelken, 2012). Bryman's research also reveals that in academia the key issue is not what leaders should do but what they should avoid: "Leadership may sometimes be as significant (if not more significant) for the damage it causes as for the benefits it brings in its wake" (2007a, p. 707). In other words, academic environments staffed by intrinsically motivated, highly educated professionals, many of whom assume leadership roles within the scope of their responsibilities, likely benefit less from effective leadership than do other environments, and the actions of leaders may be more notable for their adverse effects than for achieving the intended result.

As academics and library and information science professionals, ${ }^{16}$ academic librarians (many of whom are accomplished scholar-practitioners) expect a degree of professional autonomy and the rights and responsibilities of academic freedom and collegial governance. Centralized decision-making processes undermine fundamental needs and values of highly skilled and educated professionals, and their negative potential must be recognized. Senior leadership cannot expect engaged, much less instantaneous, support for directives developed in administrative isolation. Successful implementation and optimal results are dependent on the commitment of rank-and-file librarians. Collective ownership of decisions is particularly important during times of change or retrenchment, when moving forward is dependent on mutual consideration for organizational welfare and one's ability to move beyond individual priorities. Today it is no longer possible for any one individual or small group to be the profession's or academic library's expert, and robust decisions require insight and varying points of view. Scholars assert that the deliberative characteristic of collegial governance has the potential to find the empty space in discourse, thus highlighting what is not being said (Bradshaw \& Fredette, 2009) and to illuminate issues and give rise to potential solutions that could otherwise be missed (Meyer, 2007). Joan Wallach Scott (2015), a one-time chair of the American Association of University Professors' Committee on Academic Freedom and Tenure, makes the point that including faculty members in governance rests on the acknowledgement of their expertise, and it is this very expertise that legitimates critical scholarship and practice. For librarians, it is argued that professional expertise allows for the 
distinction between good and bad (effective and ineffective) services and discernment when boundaries of good professional practice have been breached. Wallach Scott concludes that "the faculty's role in governance... is the foundation for academic freedom" (p. 42).

\section{Conclusion}

CAUT defines collegiality as the "participation of academic staff in governance structures" and determines that academic governance must (a) allow for the expression of a diversity of views and opinions, (b) protect participants so that no individual is given inappropriate advantage (for example, due to power differentials) with respect to decisions, and (c) ensure inclusiveness so that all who should be participating are provided the opportunity to do so (CAUT, 2005). A review of the nearly 40-year history of library councils in Canadian academic libraries suggests that the collegial governance model endorsed by CAUT is perhaps something for academic libraries to aspire to, rather than something that is currently experienced. Institutional theory, which examines the relationships between the environment of an organization, the actual organization, and the employees within, helps us to understand why this may be the case. Institutional theory assumes that organizations change or conform to gain legitimacy without necessarily improving performance or efficiency. Established practices are repeated and reinforced for the sake of acceptance and fit.

Despite inefficiencies and problems associated with collegial governance, scholars insist that it is the critical check and balance that cross-examines the relevance of the leadership's vision (Bradshaw \& Fredette, 2009). What is the role of a library council, and what are the characteristics of an effective council? Research suggests that governance should be about the big picture, transparency, reflective and generative thinking, focusing on critical rather than operational issues, and asking tough questions to meet increasing complex challenges (Pennock, Jones, Leclerc, \& Li, 20I2; Bradshaw \& Fredette, 2009). As Meyer (2007) observes, excluding professionals from tough fiscal realities and decisions has the potential to adversely affect their understanding and decision-making capacity to meet future challenges. Collegial governance and management are not mutually exclusive, but it is the degree to which each is emphasized that is problematic (Kogan \& Bleiklie, 2007). It is imperative that librarians assume both professional and intellectual leadership, as well as managerial responsibility when required, that they contribute to initiative development and not just to its implementation, and that they be agents of change rather than its victims.

Further research is needed into the functions and effectiveness of existing Canadian library councils, picking up where Jacobs (2008) left off. Potential next 
steps include an examination of the bylaws or terms of reference of existing library councils or an exploration of librarians' perceptions and attitudes regarding library councils within Canadian academic libraries. Perhaps even more crucial is research into the perceptions and understanding of governance structures among senior library administrators, who are, in many cases, most able to directly effect change in library governance.

\begin{abstract}
ABOUT THE AUTHORS
Eva Revitt is the business, communication studies, and political science librarian at MacEwan University. She is also a doctoral student at the University of Alberta, Department of Educational Policy Studies. Her research interests include governance structures in higher education, educational leadership, academic freedom, labour issues in academia, and the role of the academic librarian.

Sean Luyk is the music librarian in the Rutherford Humanities and Social Sciences Library at the University of Alberta and subject librarian for anthropology. Sean holds a BMus and an MA in music criticism from McMaster University and an MLIS from the University of Western Ontario. His research interests include collegial governance in academic libraries, local music collecting, music information retrieval, and web archiving.
\end{abstract}

\title{
NOTES
}

I. See Canadian Association of University Teachers and Canadian Association of College and University Libraries (1976), CAUT (I993), CAUT (2010), and CAUT (2014).

2. See ACRL (2012).

3. Institutional theory is a set of principles developed most notably by Meyer \& Rowan (I977) and then DiMaggio \& Powell (1983) and is used to help us understand how the environment shapes and affects organizations. Institutional theory is a type of open-systems theory that in turn is situated within the wider gamut of organizational theories. See also Shafritz, Ott, \& Jang (2OII).

4. See Governance CAUT (2OI4) and Librarians' Councils, CAUT (2OI4).

5. See Freedman (2009) for a more detailed discussion regarding collegiality in the academic library and its relationship to governance.

6. The authors are unaware of provincial legislation referencing library councils. However, the existence and role of some councils are recognized by collective agreements or a senior academic body. For example, Mount Royal University Library Council reports to that university's General Faculties Council. A search of the CAUT members' database of collective agreements found eight instances where the existence of library councils is mandated in the collective agreement: Atlantic School of Theology, Brock University, Laurentian University, Mount Allison University, St. Mary's University, University of Ottawa, University of Prince Edward Island, and Wilfrid Laurier University.

7. See Ribaric (2014) for a discussion of the origins of collegial governance in Canadian universities.

8. In 2OI3-2OI4, 30 percent of CARL member libraries' staff were librarians, 62 percent were support staff, and 8 percent were "other professionals" (DeLong, Sorensen, \& Williamson, 20I5, p. IO). Of the librarians, 30 percent were in middle management or supervisory positions, a decrease of 9 percent from 2004, when 39 percent of librarians were in middle management or supervisory positions (DeLong, Sorensen, \& Williamson, 2015, p. I8).

9. See http://Laurentian.ca/collective-agreements for the most up-to-date collective agreement. 
IO. In 2013-2014, 44 percent of men were in supervisory, middle management, or senior administrative positions, compared to 46 percent of women in the same positions in CARL member libraries (DeLong, Sorensen, \& Williamson, 2015, p. 20). However, men compose only 31 percent of academic librarians.

II. According to CAUT's 2OIO-2OII/2OII-2OI2 Librarian Salary and Academic Status Survey Part I (CAUT, 20I2), of the 67 universities surveyed, librarians have academic status in almost all instances, the exceptions being Moncton University, Shippagan campus; Nipissing University; and the University of Waterloo.

I2. For example, LibQUAL+, which is a web-based survey that measures library service quality, over time and across institutions. See LibQual+, Association of Research Libraries (n.d.).

I3. The I23 members of the Berlin Philharmonic, one of the most acclaimed orchestras in the world, have input into how the Philharmonic is managed and vote to select new musicians as well as the chief conductor. For some observers, such participation is key to the Philharmonic's success. See "No news" (2015) and Slater (2015).

I4. The German work council is not a union but rather is designed to communicate suggestions and complaints. It is one of the most powerful forms of worker representation in developed countries. Most studies indicate a positive correlation between work councils and productivity. Mueller (2012) found that German firms with work councils are on average 6.4 percent more productive; however, the author also presents evidence that this figure underestimates the effect of work councils on productivity.

I5. Both Yale and Harvard were early adopters of bicameral governance, granting faculty a role in institutional decision-making in I8I7 and I826 respectively. See Gerber (2014).

16. The literature points to six factors or hallmarks that differentiate a profession from an occupation: a theoretical core that serves as the basis for professional practice, autonomy and control over one's work, intrinsic motivation, commitment to the profession and its service objectives, sense of community and accountability to peers, and professional self-monitoring through established codes of ethics. See Roberts \& Donahue (2000).

\section{REFERENCES}

Association of College \& Research Libraries. (2012). Association of College \& Research Libraries joint statement on faculty status of college and university librarians. Retrieved from HTTP://WWW.ALA.ORG/ACRL/ STANDARDS/JOINTSTATEMENTFACULTY

Association of Research Libraries. LibQual+. Retrieved from HTtp://WWW.ARL.org/Focus-AREAS/ STATISTICS-ASSESSMENT/LibQUAL\#.Vh6YHi66daR

Austin, I., \& Jones, G. A. (20I6). Governance of higher education: Global perspectives, theories and practices. New York: Routledge.

Beckman, M. (1976). Library governance. CAUT Bulletin, 24(5), 22. Retrieved from HTtPs://ARCHIVE. ORG/ STREAM/CAUtBULletin 24 _ 5\#PAGE/22/MODE/IUP

Bell, I. F., \& Watson, W. (1976). Salaries of Canadian university librarians. CAUT Bulletin, 24(5), I5-I6.

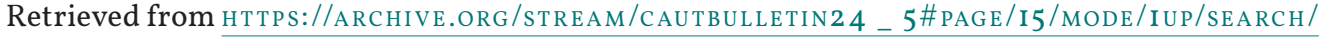
LIBRARY

Booz, Allen, \& Hamilton. (1973). Organization and staffing of the libraries of Columbia University: A case study. Westport, CT: Redgrave Information Resources Group.

Bradshaw, P., \& Fredette, C. (2009a). Academic governance of universities: Reflection of a senate chair on moving from theory to practice and back. Journal of Management Inquiry, I8(2), I23-I33. H T T P:// DX.DOI.ORG/IO.II77/IO56492608326320

Bradshaw, P., \& Fredette, C. (2009b). Theory to practice in academic governance: Not the last word. Journal of Management Inquiry, I8(2), I42-I43. H T T P://DX.D OI.ORG/IO.I I 7 7/IO56492608326328 
Bradshaw, P., \& Fredette, C. (2015). Academic governance of universities: Reflection of a senate chair on moving from theory to practice and back. Journal of Management Inquiry, I8(2), I23-I33. H T T P://DX.DOI. ORG/IO.II77/IO56492608326320

Brock University. (1990). An agreement on the terms and conditions of employment for faculty between the Brock University Faculty Association and Brock University, I3 September I990-30 June 1997. St. Catharines, ON: Brock University.

Bryman, A. (2007a). Effective leadership in higher education: A literature review. Studies in Higher Education, 32(6), 693-7IO. HTTP://DX.DOI.ORG/IO.IO80/0307507070I685II 4

Bryman, A. (2007b). Research and development series: Effective leadership in higher education summary of findings [Report]. School of Management, University of Leicester. Retrieved from HTTP://WWW.LFHE.AC.UK/ EN/COMPONENTS/PUBLICATION.CFM/Si \% 20-\%2004

Canadian Association of University Teachers and Canadian Association of College and University Libraries. (1976). Guidelines on academic status for university librarians. CAUT Bulletin, 24(5), I9-22. Retrieved from https://ARChive.org/stream/CAutbulletin2 4 _ 5\#PAge/I8/Mode/2Up/search/

Canadian Association of University Teachers. (1993). Governance \& accountability: The report of the Independent Study Group on University Governance (ISGUG). Ottawa, ON.

Canadian Association of University Teachers. (2005). Collegiality. Retrieved from H t p://wWW.CAUT.CA/ ABOUT-US/CAUT-POLICY/LISTS/CAUT-POLICY-STATEMENTS/POLICY-STATEMENT-ON-COLLEGIALITY

Canadian Association of University Teachers. (2010). Academic status and governance for librarians at Canadian universities and colleges. Retrieved from HTTP://WWW.CAUT.CA/ABOUT-US/CAUT-POLICY/LISTS/ CAUT-POLICY-STATEMENTS/POLICY-STATEMENT-ON-ACADEMIC-STATUS-AND-GOVERNANCE-FORLIBRARIANS-AT-CANADIAN-UNIVERSITIES-AND-COLLEGES

Canadian Association of University Teachers. (2012). 20IO-2OII/2OII-2OI2 librarian salary and academic status survey part I: Salaries, salary scales and academic status. Ottawa, ON.

Canadian Association of University Teachers. (20I4a). Governance. Retrieved from HT t P://WWW.CAUT.CA/ ABOUT-US/CAUT-POLICY/LISTS/CAUT-POLICY-STATEMENTS/CAUT-POLICY-STATEMENT-ON-GOVERNANCE

Canadian Association of University Teachers. (20I4b). Librarians' councils. Retrieved from HTTP://WWW. CAUT.CA/ABOUT-US/CAUT-POLICY/LISTS/CAUT-POLICY-STATEMENTS/POLICY-STATEMENT-ON-LIBRARYCOUNCILS

Canadian Association of University Teachers Librarians' Committee. (2007). CAUT Librarians' Committee discussion paper on governance and librarians. Ottawa, ON. Retrieved from ht TPS://Ut LibRARIANS. FILES. WORDPRESS.COM/2OII/I2/GOVERNANCE_LIBRARIANS-CAUT-PAPER.PDF

Crellin, M. A. (2010). The future of shared governance. New Directions for Higher Education, I5I, 7I-8I. HTTP://DX.DOI.ORG/IO.IOO2/HE.4O2

Cunningham, B. M. (2009). Faculty: Thy administrator's keeper? Some evidence. Economics of Education Review, 28(4), 444-453. HTTP://DX.DOI.ORG/IO.IOI6/J.ECONEDUREV.2008.07.005

DeLong, K., Sorensen, M., \& Williamson, V. (2015). 8Rs redux CARL libraries human resources study. Retrieved from HTTP://WWW.CARL.ABRC.CA/UPLOADS/PDFS/8RS-REDUX-FINAL-REPORT-JUNE-2OI5.PDF

DiMaggio, P. J. \& Powell, W. W. (1983). The iron cage revisited: Institutional isomorphism and collective rationality in organizational fields. American Sociological Review, 48(2), I47-I60. Retrieved from н т т:// WWW.JSTOR.ORG/STABLE/2O95IOI

Eadie, T. (1978). Librarians and collective bargaining. CAUT Bulletin, 25(7), I3-I4. Retrieved from HtTps:// ARCHIVE.ORG/STREAM/CAUTBULLETIN25 _ 7\#PAGE/I3/MODE/IUP/SEARCH/LIBRARY

Eckel, P. D. (2000). The role of shared governance in institutional hard decisions: Enabler or antagonist? Review of Higher Education, 24(I), I5-39. HT TP://DX.DOI.ORG/IO.I353/RHE. 2000.0022

Ellis, R. H. (I980). Putting policy in the stacks. CAUT Bulletin, 27(5), 9-IO. Retrieved from Hтt ps:// ARCHive.org/stream/CAutbulLETIN 27 _ 5\#PAGE/9/MODE/IUP 
Evans, C. D. (1976). Librarians and CAUT: Historical overview and future directions. CAUT Bulletin, 24(5), I2-I3. Retrieved from https://ARchive.org/Stream/CAUtbulLetin24 _ 5\#PAge/I2/MOde/2Up/ SEARCH/LIBRARY

Freedman, S. (2009). Collegiality matters: How do we work with others. Paper presented at the Charleston Library Conference, Charleston, VA. Retrieved from HTTP://Docs.LIB.PURDUE.EDU/CGI/ VIEWCONTENT.CGI?ARTICLE=IO54\&CONTEXT = CHARLESTON

Gerber, L. G. (2OI4). The rise and decline of faculty governance: Professionalization and the modern American university. Baltimore: Johns Hopkins University Press.

Granfield, D., Kandiuk, M., \& Sonne de Torrens, H. (2OII). Academic librarianship: A crisis or an opportunity? Partnership: The Canadian Journal of Library and Information Practice and Research, 6(2), I-6. Retrieved from HTtps://JOURnAL.LIB.UOGUELPH.CA/InDEX.PHP/PERJ/ARTICLE/VIEW/I678/2257\#. VH6ZRC66DAQ

Griffith, R. (1993). Budget cuts and shared governance: An administrator's perspective. Academe, 79(6), I5-I7. HTTP://DX.DOI.ORG/IO.2307/4025056I

Institute on Governance. (2015). Defining governance: What is governance? Retrieved from HT P://IOG.CA/ DEFINING-GOVERNANCE/

Jacobs, L. (2008). Library councils in Canadian academic libraries: A summary of responses [Report]. Retrieved from https://WWW.ULETH.CA/DSPACE/HANDLE/IOI33/564

Jones, G. A., Shanahan, T., \& Goyan, P. (200I). University governance in Canadian higher education. Tertiary Education and Management, 7(2), I35-I48. HT T P://DX.DOI.ORG/IO.IO80/I3583883.200I.99670 $\underline{47}$

Kogan, M., \& Bleiklie, I. (2007). Organization and governance of universities. Higher Education Policy, 2O(4), 477-493. HTTP://DX.DOI.ORG/IO.IO57/PALGRAVE.HEP.8300I67

Koufogiannakis, D. (2015). Determinants of evidence use in academic librarian decision making. College \& Research Libraries 76(I), IOO-II4. HTTP://DX.DOI.ORG/IO.5860/CRL.76.I.IOO

Librarians join Carleton faculty union.(I975). CAUT Bulletin, 23(6), 6. Retrieved from HTtps://ARCHIVE. oRg/STREAM/CAUtBulletin23 _ 6\#PAGE/6/MODE/2UP

MacPherson, L. (1977). Rank or classification for librarians? CAUT Bulletin, 26(4), Io. Retrieved from HTtps://ARChive.org/stream/CAutbulletin25 _ 4\#PAGE/IO/MOde/IUP

Masleck, C. (1975). Carleton ratifies first collective agreement. CAUT Bulletin, 24(3), I-3. Retrieved from

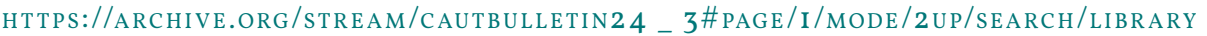

McGregor Rodney, H. (1976). Threats to intellectual freedom experienced by professional librarians in Canadian college and university libraries. CAUT Bulletin, 24(5), I7-I8. Retrieved from H T TPs:// ARCHIVE.ORG/StREAM/CAUTBULLETIN2 4 _ 5\#PAGE/I7/MODE/2UP/SEARCH/LIBRARY

Meyer, L. H. (2007). Collegial participation in university governance: A case study of institutional change. Studies in Higher Education, 32(2), 225-235. H T T P://DX.DOI.ORG/IO.IO 80/O 307507070I267269

Meyer, L. H., \& Evans, I. M. (2003). Motivating the professoriate: Why sticks and carrots are only for donkeys. Higher Education Management and Policy, I5(3), I5I-I67. Retrieved from H T T P://WWW.OECD.ORG/ EDU/IMHE/37443600.PDF

Meyer, J. W., \& Rowan, B. (1977). Institutional organizations: Formal structure as myth and ceremony. American Journal of Sociology, 83(2), 340-363. HT TP://DX.DOI.ORG/IO.IO 86/226550

Miles, J. A. (2012). Management and organizational theory: A Jossey-Bass reader. San Francisco: Jossey-Bass.

Monty, V. (I977). Professional librarians at York. CAUT Bulletin, 26(4), IO. Retrieved from ht t ps://ARChive. org/STREAM/CAUTBULLETIN25 _ 4\#PAGE/IO/MODE/IUP/SEARCH/LIBRARY

Moore, K. B. (1976). Collective bargaining for librarians. CAUT Bulletin 24(5), I4-15. Retrieved from HTtPS://ARCHIVE.ORG/StREAM/CAUTBULLETIN24_5\#PAGE/I 4/MODE/2UP/SEARCh/LIBRARY 
Moore, R. (1988). Library councils offer weak form of collegiality, governance. CAUT Bulletin, 35(5), 9. Retrieved from https://ARchive.org/Stream/CAUtbulletin35 _ 5\#PAgE/9/MOde/IUP

Mueller, S. (2012). Works councils and establishment productivity. Industrial and Labor Relations Review, 65(4), 880-898.

No news from the Berliner Philharmoniker. (2015, May II). Gramophone: The World's Best Classical Music Reviews. Retrieved from htTp://WWW.GRAMOPHONE.CO.UK/CLASSICAL-MUSIC-NEWS/NO-NEWS-FROMTHE-BERLINER-PHILHARMONIKER

Oakleaf, M. (20I0). The value of academic libraries: A comprehensive research review and report. Chicago: Association of College \& Research Libraries. Retrieved from HTTP://WWW.ALA.org/ACRL/SITES/ALA. ORG.ACRL/FILES/CONTENT/ISSUES/VALUE/VAL_ REPORT.PDF

Olsen, D. (1993). Work satisfaction and stress in the first and third year of academic appointment. Journal of Higher Education, 64(4), 453-47I. HTTP://DX.DOI.ORG/IO.2307/2960052

Pennock, L., Jones, G. A., Leclerc, J. M., \& Li, S. X. (2OI2). Academic senates and university governance in Canada: Changes in structures and perceptions of senate members. Paper presented at the Consortium of Higher Education Researchers, Belgrade, Serbia. Retrieved from HT P://ww w. oise.utoronto.ca/hec/UserFiles/File/Research/PAPERs/SEnAte_PAPER _ FOR _ CHER CONFERENCE_2OI2-O8-3O.DOCX

Peters, D. (1999). The librarians' committee today. CAUT Bulletin, 46(6), 2. Retrieved from H tт ps:// ARCHIVE.ORG/StREAM/CAUTBULLETIN4 6 _ 6\#PAGE/I2/MODE/IUP

Petter, C. (2012). Librarians, governance, and the "Petch Procedures" at the University of Victoria. Paper presented at the Confederation of University Faculty Associations of British Columbia Conference, Vancouver, BC. Retrieved from HTtP://WWW.CUFA.BC.CA/WP-CONTENT/UPLOADS/2OI5/II/ACADEMICGOVERNANCE-3.O.PDF

Ribaric, T. (2OI4). Collegial self-governance for professional librarians: The establishment and evolution of a library council at Brock University. In J. Dekker \& M. Kandiuk (Eds.), In Solidarity (pp. 277-289). Sacramento, CA: Library Juice Press.

Ridley, M. (20I4). Returning to the ranks: Towards a holistic career path in academic librarianship. Partnership: The Canadian Journal of Library and Information Practice and Research, 9(2), I-9. Retrieved from HTtPs://JOURNAL.Lib.UOGUELPH.CA/INDEX.PHP/PERJ/ARTICLE/VIEW/3060\#.Vh6POC66DAQ

Roberts, K. A., \& Donahue, K. A. (2000). Professing professionalism: Bureaucratization and deprofessionalization in the academy. Sociological Focus, 33(4), 365-383. Retrieved from H T T P://DX.DOI. ORG/IO.IO80/00380237.2000.1057II75

Scott, W. R. (2005). Institutional theory. In G. Ritzer (Ed.), Encyclopedia of social theory (pp. 408-4I4). Thousand Oaks, CA: Sage.

Shafritz, J. M., Ott, J. S., \& Jang, Y. S. (20II). Classics of organization theory. Boston: Wadsworth Cengage Learning.

Sheeran, R., et al. (1997). University governance and the recognition of academic librarians. CAUT Bulletin, 44(6), supplement, I-4. Retrieved from HTTPS://ARCHIVE. ORG/STREAM/ CAUTBULLETIN 44 _ 6\#PAGE/I3/MODE/IUP

Sheeran, R. (1998). An active role for librarians. CAUT Bulletin, 45(5). Retrieved from H t t ps://www. CAutbulletin.ca/en _ ARticle.asp?Articleid =2388

Sim, V. (1979). Librarians discuss advancement difficulties at Western conference. CAUT Bulletin, 26(6), 5-6. Retrieved from https://Archive.org/stream/CAutbulletin26_6\#Page/5/Mode/Iup

Slater, J. (2015, May I2). Berlin Philharmonic deadlocked in vote for new maestro. Globe and Mail. Retrieved from HTTP://WWW.THEGLOBEANDMAIL.COM/NEWS/WORLD/BERLIN-PHILHARMONIC-VOTE-INSECRET-TO-REPLACE-CONDUCTOR/ARTICLE $24363604 /$

Sporn, B. (2006). Governance and administration: Organizational and structural trends. In J. J. F. Forest \& P. G. Altbach (Eds.), International handbook of higher education (pp. I4I-I57). Dordrecht: Springer. 
Steele, K. (20IO). The changing Canadian PSE landscape. In J. Black (Ed.), Strategic enrolment intelligence: Canada's first book on strategic enrolment management (pp. 27-49). London, ON: Academica Group.

St. Jacques, S. (1988). Library governance. CAUT Bulletin, 35(9), I5. Retrieved from HTT Ps://ARCHIVE. ORG/ STREAM/CAUTBULLETIN 35 _ 9\#PAGE/I5/MODE/IUP

Teelken, C. (2OI2). Compliance or pragmatism: How do academics deal with managerialism in higher education? A comparative study of three countries. Studies in Higher Education, 37(3), 27I-290. H T T P:// DX.DOI.ORG/IO.IO80/03075079.20IO.5III7I

Thompson, A. (I977). C.A.U.T. / C.A.C.U.L. document at Laurentian. CAUT Bulletin, 26(4), IO-II. Retrieved from https://ARChive.org/stream/CAutbulletin25 _ 4\#PAge/IO/MOde/IuP

Vine, R. (1988). Using an internal library committee for dispute resolution. CAUT Bulletin, 35(9), I4. Retrieved from https://ARchive.org/stream/CAUtbulletin35 _ 9\#PAGE/I 4/MOde/IUP

Wallach Scott, J. (2002). The critical state of shared governance. Academe, 88(4), 4I-48. H T T P://DX.DOI. ORG/IO.2307/40252I88 